\title{
Action of Trivalent Chromium on Rat Liver Structure. Histometric and Haematological Studies
}

\author{
Acción del Cromo Trivalente sobre las Estructuras Hepáticas de Ratas. \\ Estudios Histométrico y Hematológico \\ "Rogério Ferreira da Silva; ",** Ruberval A. Lopes; "**Miguel A. Sala; "Dionísio Vinha; \\ ${ }^{* *}$ Simone C. H. Regalo; ${ }^{* * *}$ Ana Maria de Souza \& ${ }^{* * *}$ Zita Maria de O. Gregório.
}

SILVA, R. F.; LOPES, R. A.; SALA, M. A.; VINHA, D.; REGALO, S. C. H.; SOUZA, A. M. \& GREGÓRIO, Z. M. O. Action of trivalent chromium on rat liver structure. Histometric and hematological studies. Int. J. Morphol., 24(2):197-203, 2006.

SUMMARY: The trace mineral trivalent chromium $\left(\mathrm{Cr}^{3+}\right)$ is an essential nutrient involved in the regulation of carbohydrate, lipid and protein metabolism via an enhancement of insulin action. The present work had as objective to characterize histopathologically and histometrically the hepatic alterations of female Wistar rats, determined by the chromium III administration in drinking water. Adult rats received ration and drinking water ad libitum containing 300 or $500 \mathrm{mg} / \mathrm{l}$ chromium III during 4 months. Control animals received only water and ration. All animals were sacrificed by lethal dose of anesthetic. Samples of liver were fixed in $10 \%$ formalin for $24 \mathrm{~h}$. Tissues for microscopical pathology were processed using standard procedures. Paraffin sections prepared at $6 \mu \mathrm{m}$ were stained with haematoxylin and eosin and PAS. Besides the histopathological exam, histometrical techniques were used. The blood was collected and processed for hematological study. Histopathological analysis revealed periportal, midzonal and pericentrilobular zones with parenchyma cells with varying degrees of vacuolation. Many hepatocytes are ballooned and the nuclei were in lysis. The centrilobular vein was dilated and congested. Dilated sinusoids containing erythrocytes were observed. The portal area showed fibrosis, biliar duct proliferation with small cells. Histometric study showed increased cytoplasm and cell volumes, and small values for number of hepatocytes per $\mathrm{mm}^{3}$. Lymphopenia was observed in $500 \mathrm{mg} / \mathrm{l} \mathrm{Cr}^{3+} / \mathrm{l}$ treated animals. These results indicate that the chromium III has a direct participation in liver structures alterations.

KEY WORDS: Liver; Rat; Chromium; Morphometry; Hematology.

\section{INTRODUCTION}

The trace mineral trivalent chromium $\left(\mathrm{Cr}^{3+}\right)$ is an essential nutrient involved in the regulation of carbohydrate, lipid, and protein metabolism via an enhancement of insulin action (Anderson, 1986, 1989, 1993). Mammals need $\mathrm{Cr}^{3+}$ to maintain balanced glucose metabolism (Mertz, 1975), and thus chromium may facilitate insulin action (Nielsen, 1993, Vincent, 1999), and has an anabolic function (Evans, 1989). $\mathrm{Cr}^{6+}$ is much more toxic than the trivalent form. $\mathrm{Cr}^{3+}$ has a low order of toxicity, and a wide margin of safety exists between the amounts usually ingested. It is unlikely to induce deleterious effects. The $\mathrm{Cr}^{3+}$ ion becomes toxic only at extremely high doses; $\mathrm{Cr}$ acts as a gastric irritant rather than as a toxic element that adversely affects physiology and metabolism (Lukaski, 1999). Following parenteral administration, the most common systemic effects of $\mathrm{Cr}$ were parenchymatous changes in the liver and kidney (Mosinger \& Fiorentini, 1954).

Since Cr compounds are increasingly present in products used in daily life, $\mathrm{Cr}$ eczemas are often observed in the general population. Polak et al. (1973) surveyed the most important Cr-containing materials or objects: $\mathrm{Cr}$ ore, baths, colors, lubricating oils, anti-corrosive agents, wood preservation salts, cement, cleaning materials, textiles, and leather tanned with $\mathrm{Cr}$. According to Polak et al., people who work with material containing mere traces of Cr salts are more at risk than workers who come into contact with high concentration of $\mathrm{Cr}$ salts. Some less frequently occurring

* University of Franca, Brazil.

* Faculty of Odontology of Ribeirão Preto, University of São Paulo, Brazil.

**** Faculty of Pharmaceutical Sciences of Ribeirão Preto, University of São Paulo, Brazil.

Supported by Universidade of Franca (UNIFRAN), Brazil.

Master Science Dissertation of the first author, presented to the University of Franca, Brazil (Health Promotion Area). 
cases includes sensitization by tattooing (especially green and light-blue) (Tazelaar, 1970), artificial dentures made by Cr-containing steel, metal pins used for internal fixation of broken bones, and bullets retained in the body (Langard \& Hensten-Pettersen, 1981).

The purpose of the present study was to assess the effect of high-dose $\mathrm{Cr}^{3+}$ supplementation on rat liver structure and on hematological parameters.

\section{MATERIAL AND METHOD}

Fifteen female Wistar rats (Rattus norvegicus), weighing $170 \mathrm{~g}$, were housed in three plastic cages $(\mathrm{n}=5$ each) with stainless steel cover lids and white pinus shavings as bedding, under controlled conditions of light (12 h-light/ 12 h-dark cycle), humidity $(50 \pm 10 \%)$, and fed with commercial pelleted rodent chow ad libitum.

The dosage levels in this study were: 300 and 500 $\mathrm{mg} \mathrm{Cr}{ }^{3+} / 1$ drinking water, during 4 months. A control group received water only.

All rats were sacrificed with $3 \%$ Hypnol $®$ at the end of the experimental period. Samples of liver were fixed in $10 \%$ formalin for $24 \mathrm{~h}$. Paraffin sections prepared at $6 \mu \mathrm{m}$ were stained with hematoxylin and eosin, and periodic acid + Schiff (PAS).

Karyometry. The nuclear measurements of hepatocytes and cholangiocytes of control $(\mathrm{C})$ and treated $(\mathrm{T})$ rats were estimated according to Sala et al. (1994). The longest (D) and shortest (d) axis were measured in the drawing of each nucleus in order to estimate the following nuclear parameters: geometric mean diameter, D/d ratio, perimeter, area, volume, V/A ratio, shape factor, contour index, and eccentricity.

Stereology. Stereological analysis was performed on the drawing of the liver, obtained by a projection on a 100 point test grid (Merz, 1968), with a final magnification of 1,000x. Stereological methods were used to estimate the N/C ratio, cytoplasm and cell volumes, and the numeric density of hepatocytes (Sala et al., 1992).

Hematological parameters. Heparinized blood was obtained from heart puncture of each animal under 3\% Hypnol® anesthesia. Red blood cell count (RBC), hemoglobin content $(\mathrm{Hb})$, haematocrit (Hct), mean corpuscular volume (MCV), mean corpuscular hemoglobin $(\mathrm{MCH})$, mean corpuscular hemoglobin concentration (MCHC), white blood cell count (WBC), and the percentage of basophiles, eosinophils, segmented neutrophils, lymphocytes and monocytes were determined using standard techniques.

The data were statistically analyzed using the nonparametric Wilcoxon-Mann-Whitney test.

\section{RESULTS}

The general histological picture showed periportal, midzonal and pericentrilobular regions with parenchyma cells with varying degrees of vacuolation. Many cells are ballooned and have feathery, lightly staining cytoplasm. The centrilobular vein was dilated and congested. In portal area is evident the peribiliary fibrosis and bile duct hyperplasia. PAS-positive material may result in a vacuolated appearance of the hepatocytes (Figs. 1, 2, 3 and 4).

Morphometrical evaluation of the hepatocyte nuclei showed that the longest, shortest and mean diameters, D/d ratio, perimeter, area, volume and V/A ratio were similar to that control animals. No alteration was observed in the shape of the hepatocyte nuclei (Table I).

Stereological study showed that cytoplasm and cell volumes values are significantly higher from the treated rats; showed, also, that N/C ratio and numeric density of hepatocytes are smaller in those animals (Table II).

The hematological parameters were normal, only a slight lymphocytopenia was seen (Table III).

\section{DISCUSSION}

In rat, the absorbed chromium was transferred to the liver where the liver tissue retained $10.9 \%$ of chromium oxide and $51.1 \%$ of sodium chromate. Different absorption rate of chromate depending on the route of administration could be due to the fact that the hexavalent form given orally was reduced to $\mathrm{Cr}^{3+}$ in the acidic environment of the stomach (Febel et al., 2001). In this work, the $\mathrm{Cr}^{3+}$ was given orally at dosage 300 and $500 \mathrm{mg} \mathrm{Cr}^{3+} / 1$ drinking water, during 4 month were transferred to the liver and exert its effects on hepatocytes.

The ballooned hepatocytes of rats treated with 300 and $500 \mathrm{mg} \mathrm{Cr}^{3+}$ received support on stereological data with higher cytoplasm and cell volumes with smaller cell number density. 


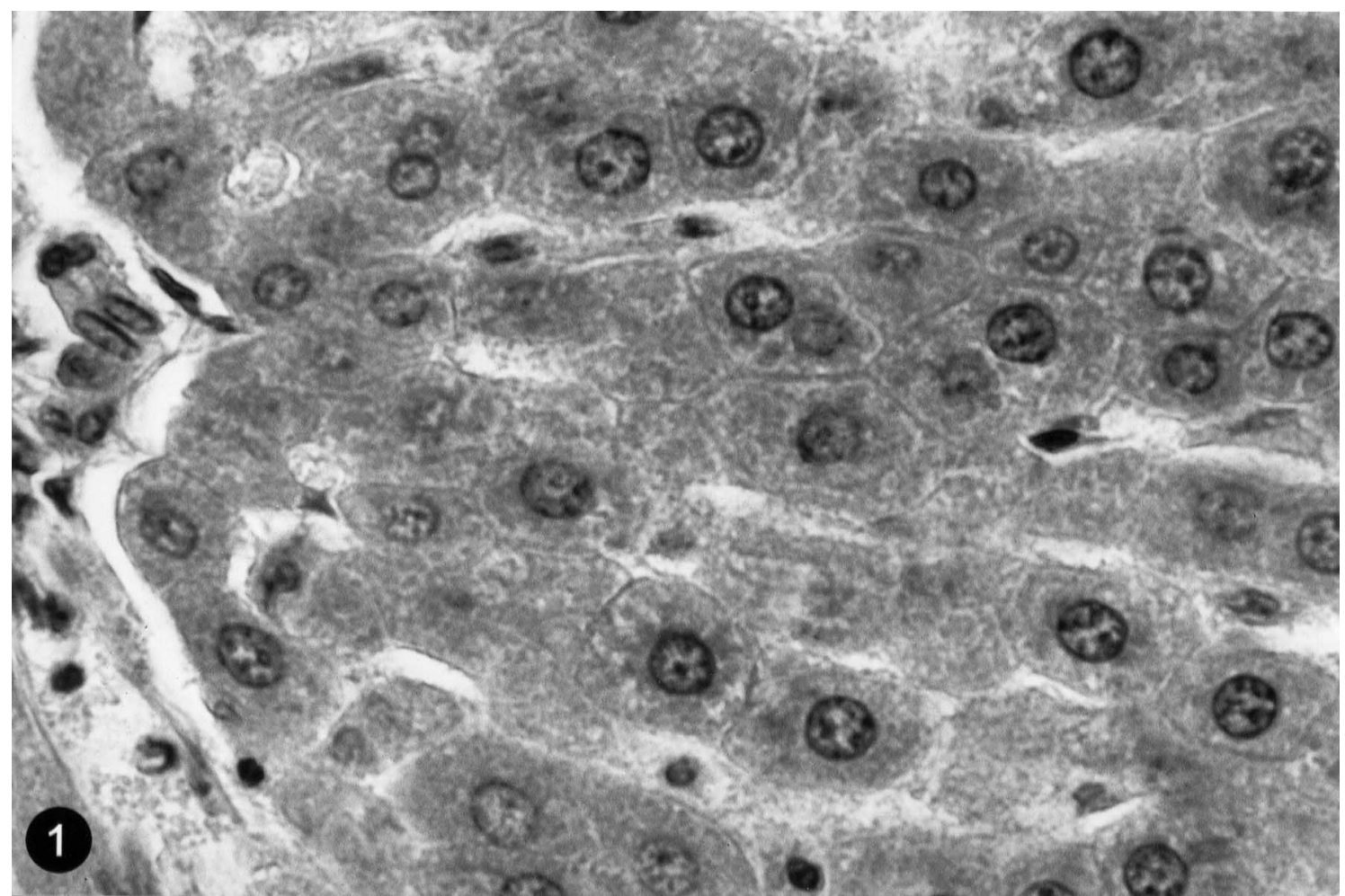

Fig. 1. Histological picture of control rat liver. HE (900x).

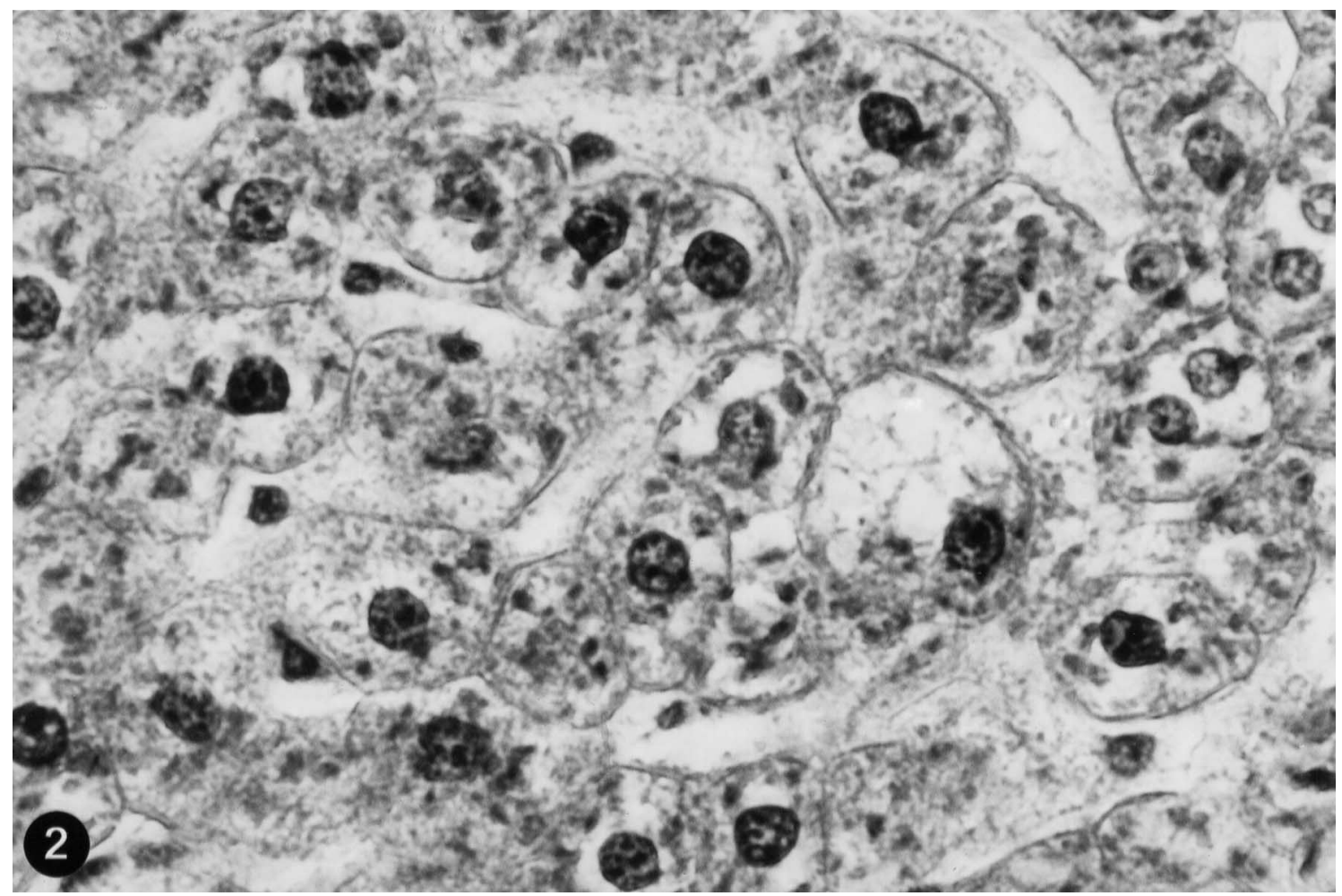

Fig. 2. Histological picture of treated rat (T300) liver. Note hepatocytes ballooned full of glycogen. HE (900x). 


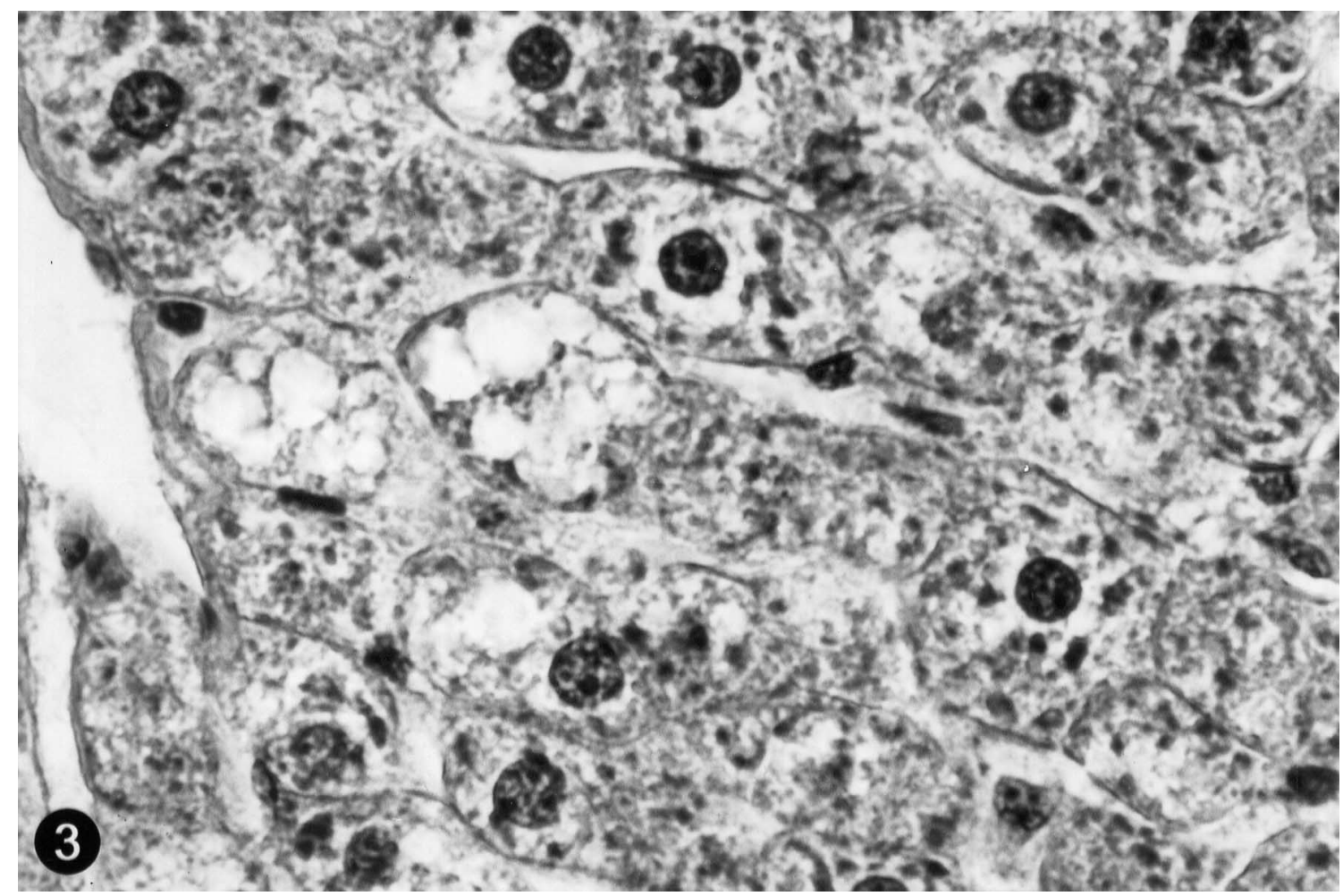

Fig. 3. Histological picture of treated rat (T500) liver. Note hepatocytes with varying degrees of vacuolation. HE (900x).

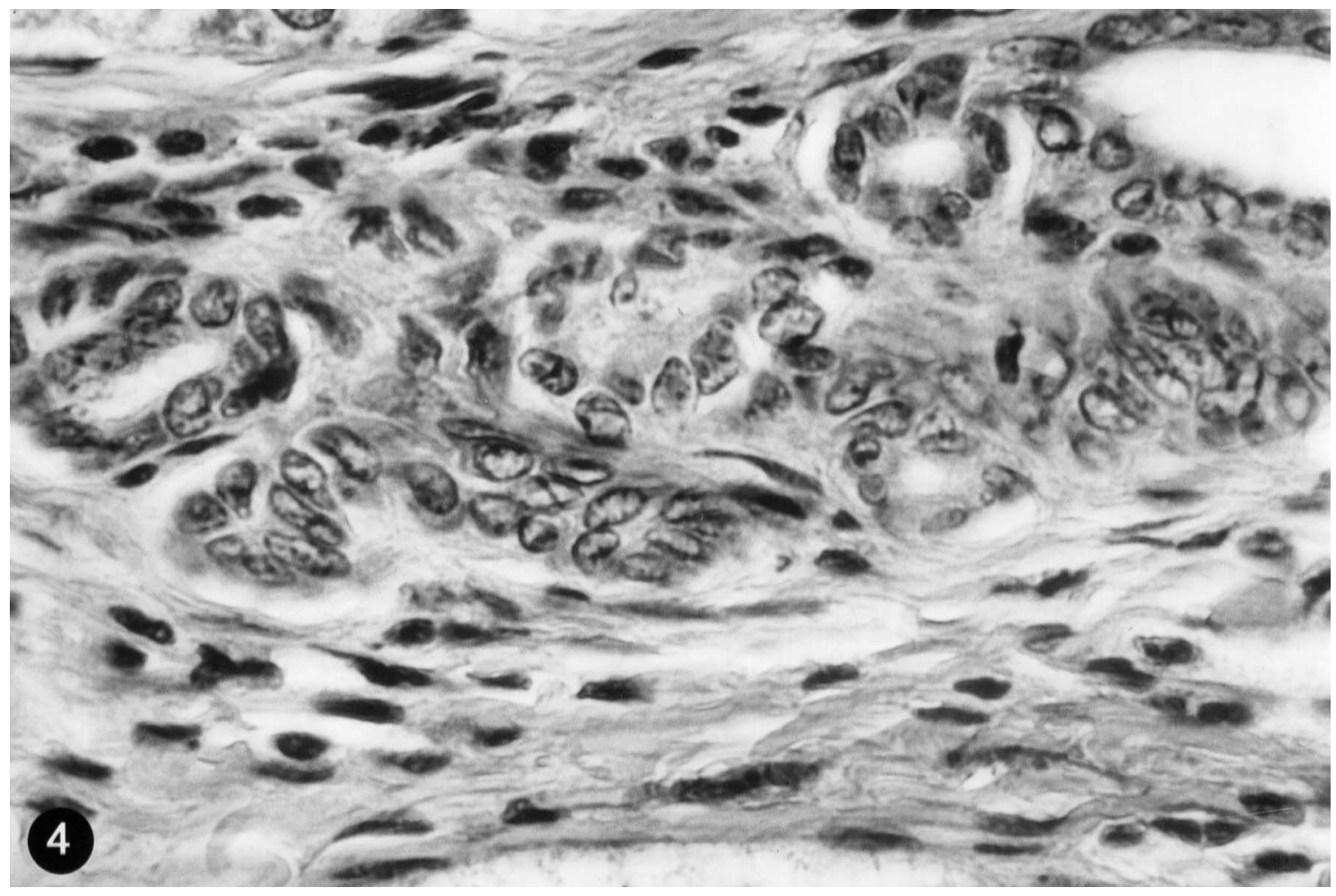

Fig. 4. Histological picture of treated rat (T500) liver. Note the portal area with fibrosis and biliar duct proliferation. HE (900x). 
Table I. Mean values of karyometric parameters of hepatocytes of control (C) and chromium-treated (T300 and T500) rats. WilcoxonMann-Whitney test.

\begin{tabular}{|c|c|c|c|c|c|c|c|c|c|}
\hline \multirow{3}{*}{ Parameter } & \multicolumn{3}{|c|}{ Group of animals } & \multicolumn{6}{|c|}{ Wilcoxon-Mann-Whitney test } \\
\hline & \multirow[b]{2}{*}{$\mathbf{C}$} & \multirow[b]{2}{*}{$\mathbf{T}_{300}$} & \multirow[b]{2}{*}{$\mathbf{T}_{500}$} & \multicolumn{2}{|c|}{$\mathrm{C} \times \mathrm{T}_{300}$} & \multicolumn{2}{|c|}{$\mathrm{C} \times \mathrm{T}_{500}$} & \multicolumn{2}{|c|}{$\mathbf{T}_{300} \times \mathbf{T}_{500}$} \\
\hline & & & & Ucalc & $\mathbf{P}[\mathbf{U}]$ & Ucalc & $\mathbf{P}[\mathbf{U}]$ & Ucalc & $\mathbf{P}[\mathbf{U}]$ \\
\hline Longest axis $(\mu \mathrm{m})$ & 7.25 & 7.26 & 7.42 & 12 & 0.500 & 9 & 0.274 & 6 & 0.111 \\
\hline Shortest axis $(\mu \mathrm{m})$ & 5.90 & 6.03 & 6.07 & 9 & 0.274 & 9 & 0.274 & 10 & 0.345 \\
\hline Mean axis $(\mu \mathrm{m})$ & 6.52 & 6.60 & 6.71 & 12 & 0.500 & 8 & 0.210 & 7 & 0.115 \\
\hline $\mathrm{D} / \mathrm{d}$ ratio & 1.24 & 1.22 & 1.23 & 8 & 0.210 & 9 & 0.274 & 7 & 0.115 \\
\hline Perimeter $(\mu \mathrm{m})$ & 20.72 & 20.94 & 21.26 & 12 & 0.500 & 8 & 0.210 & 6 & 0.111 \\
\hline Area $\left(\mu \mathrm{m}^{2}\right)$ & 34.14 & 34.78 & 36.09 & 11 & 0.421 & 9 & 0.274 & 6 & 0.111 \\
\hline Volume $\left(\mu \mathrm{m}^{3}\right)$ & 154.88 & 158.03 & 168.00 & 11 & 0.421 & 9 & 0.274 & 6 & 0.111 \\
\hline V/A ratio $(\mu \mathrm{m})$ & 4.35 & 4.40 & 4.47 & 12 & 0.500 & 8 & 0.210 & 7 & 0.115 \\
\hline Shape factor & 0.98 & 0.98 & 0.98 & 7 & 0.115 & 10 & 0.345 & 12 & 0.500 \\
\hline Contour index & 3.58 & 3.58 & 3.58 & 9 & 0.274 & 9 & 0.274 & 9 & 0.274 \\
\hline Eccentricity & 0.53 & 0.49 & 0.56 & 6 & 0.111 & 12 & 0.500 & 11 & 0.421 \\
\hline
\end{tabular}

All not significant

Table II. Mean values of stereological parameters of hepatocytes of control (C) and chromium-treated (T300 and T500) rats. WilcoxonMann-Whitney test.

\begin{tabular}{|c|c|c|c|c|c|c|c|c|c|}
\hline \multirow{3}{*}{ Parameter } & \multicolumn{3}{|c|}{ Group of animals } & \multicolumn{6}{|c|}{ Wilcoxon-Mann-Whitney test } \\
\hline & \multirow[b]{2}{*}{$\mathbf{C}$} & \multirow[b]{2}{*}{$\mathbf{T}_{300}$} & \multirow[b]{2}{*}{$\mathbf{T}_{500}$} & \multicolumn{2}{|c|}{$\mathrm{C} \times \mathrm{T}_{\mathbf{3 0 0}}$} & \multicolumn{2}{|c|}{$\mathrm{C} \times \mathrm{T}_{500}$} & \multicolumn{2}{|c|}{$\mathbf{T}_{300} \times \mathbf{T}_{500}$} \\
\hline & & & & Ucalc & $\mathbf{P}[\mathbf{U}]$ & Ucalc & $\mathbf{P}[\mathbf{U}]$ & Ucalc & $\mathbf{P}[\mathbf{U}]$ \\
\hline Cytoplasm volume $\left(\mu \mathrm{m}^{3}\right)$ & 1880.01 & 4838.21 & 5074.58 & $0 *$ & 0.004 & $0^{*}$ & 0.004 & 8 & 0.210 \\
\hline Cell volume $\left(\mu \mathrm{m}^{3}\right)$ & 2034.89 & 4996.25 & 5242.58 & $0 *$ & 0.004 & $0^{*}$ & 0.004 & 8 & 0.210 \\
\hline $\mathrm{N} / \mathrm{C}$ ratio & 0.077 & 0.037 & 0.032 & $0 *$ & 0.004 & $0^{*}$ & 0.004 & 8 & 0.210 \\
\hline Numerical density $\left(\mathrm{N} / \mathrm{mm}^{3}\right)$ & 494535.4 & 238252.1 & 201193.1 & $0 *$ & 0.004 & $0 *$ & 0.004 & 7 & 0.115 \\
\hline
\end{tabular}

* Statistically significant at $\mathrm{p}<0.01$

Table III. Mean values of hematological parameters of control (C) and chromium-treated (T300 and T500) rats. Wilcoxon-Mann-Whitney test.

\begin{tabular}{|c|c|c|c|c|c|c|c|c|c|}
\hline \multirow{3}{*}{ Parameter } & \multicolumn{3}{|c|}{ Group of a nimals } & \multicolumn{6}{|c|}{ Wilcoxon-Mann-Whitney test } \\
\hline & \multirow[b]{2}{*}{$\mathbf{C}$} & \multirow[b]{2}{*}{$\mathbf{T}_{300}$} & \multirow[b]{2}{*}{$\mathbf{T}_{500}$} & \multicolumn{2}{|c|}{$\mathbf{C} \times \mathbf{T}_{300}$} & \multicolumn{2}{|c|}{$\mathbf{C} \times \mathbf{T}_{500}$} & \multicolumn{2}{|c|}{$\mathbf{T}_{300} \times \mathbf{T}_{500}$} \\
\hline & & & & Ucalc & $\mathbf{P}[\mathbf{U}]$ & Ucalc & $\mathbf{P}[\mathbf{U}]$ & Ucalc & $\mathbf{P}[\mathbf{U}]$ \\
\hline $\operatorname{RBC}\left(10^{6} / \mathrm{mm}^{3}\right)$ & 5.7 & 5.6 & 5.6 & 8 & 0.210 & 7 & 0.115 & 9 & 0.274 \\
\hline Hct $(\%)$ & 46.6 & 46.0 & 45.6 & 10 & 0.345 & 10 & 0.345 & 12 & 0.500 \\
\hline $\mathrm{Hb}(\mathrm{g} / \mathrm{dl})$ & 14.1 & 13.8 & 13.8 & 10 & 0.345 & 10 & 0.345 & 12 & 0.500 \\
\hline $\operatorname{MCV}(\mathrm{fl})$ & 81.7 & 82.5 & 81.7 & 12 & 0.500 & 10 & 0.345 & 10 & 0.345 \\
\hline $\mathrm{MCH}(\mathrm{pg})$ & 24.7 & 24.7 & 24.9 & 9 & 0.274 & 11 & 0.421 & 11 & 0.421 \\
\hline $\mathrm{MCHC}(\mathrm{g} / \mathrm{dl})$ & 30.2 & 29.9 & 30.4 & 9 & 0.274 & 8 & 0.210 & 5 & 0.075 \\
\hline WBC $\left(\mathrm{N} / \mathrm{mm}^{3}\right)$ & 5,200 & 5,460 & 5,080 & 7 & 0.115 & 11 & 0.421 & 6 & 0.111 \\
\hline Basophils (\%) & 0 & 0 & 0 & - & - & - & - & - & - \\
\hline Eosinophils (\%) & 1.8 & 1.8 & 2.4 & 12 & 0.500 & 8 & 0.210 & 8 & 0.210 \\
\hline Neutrophils (\%) & 21.2 & 25.2 & 26.0 & 10 & 0.345 & 6 & 0.111 & 9 & 0.274 \\
\hline Lymphocytes (\%) & 72.0 & 70.0 & 67.0 & 11 & 0.421 & $4 *$ & 0.048 & 11 & 0.421 \\
\hline Monocytes (\%) & 4.2 & 2.8 & 4.0 & 7 & 0.115 & 12 & 0.500 & 7 & 0.115 \\
\hline
\end{tabular}

* Statistically significant at $\mathrm{p}<0.05$

A plausibly explanation of those cellular alterations would be: the chromium induces significant increase in membrane cholesterol level as well as significant decrease in membrane phospholipids level in chromium exposed rat suggest structural alterations of both liver and kidney plasma membrane. The alkaline phosphatase, total ATPase and $\mathrm{Na}^{+}-\mathrm{K}^{+}$-ATPase activities of plasma membrane were significantly decreased in both liver and kidney after chromium treatment (Dey et al., 2003). The membrane becomes more permeable with water and glucose entrance in hepatocyte cytoplasm. Membrane damage can be restrained with the supplementation of alpha-tocopherol (Dey et al., 2003) and ascorbic acid (Dey et al., 2001).

In this work hepatocytes full of clear vacuoles were seen, probably of glycogen intensely stained by PAS. Mammals need $\mathrm{Cr}^{3+}$ to maintain balanced glucose metabolism (Mertz), and thus chromium may facilitate insulin action (Nielsen and Vincent). These observations plus higher plasma membrane permeability result on data observed in this work. 
Administration of $\mathrm{Cr}^{3+}$ to mice caused accumulation of chromium in the hepatocyte nucleus, which amounted to about $20 \%$ of the accumulated chromium content of the liver cell, and also enhanced RNA synthesis. $\mathrm{Cr}^{6+}$ inhibits RNA synthesis (Okada et al., 1983). Rats pretreated with $\mathrm{Cr}^{3+}$ intraperitoneally, and then subjected to partial hepatectomy concentrated chromium in the regenerating liver cells, especially in the nucleoli (Okada et al., 1984). These data suggests a direct participation of chromium in the RNA synthesis. In 1959, Wacker \& Vallee reported that $\mathrm{Cr}^{3+}$ was present in RNA from all sources examined; they hypothesized that chromium might contribute to the stabilization of the structure.

In this work hepatocytes nuclei of treated rats were similar to that control. Morphometrical evaluation showed that longest, shortest and mean diameters, D/d ratio, perimeter, area, volume and V/A ratio confirm these observations. No alteration was observed in the shape of the cells. Numerous cells in apoptosis were seen.

Marked histopathological changes as sinusoids, centrilobular vein and portal vessels congestion were seen in this material, quite similar to those observed in rabbits by Tandon et al. (1978). The presence of biliar ducts proliferation was also similar to that observed in rabbits by Tandon et al.

The fibrosis observed in portal area can be explained by the fibrogenic effects of chromium. A single intratracheal injection of chromite particles caused a moderate reaction in rats (Swensson, 1977) and mice (Davies, 1972). Whereas fibroblasts normally grow as elongated cells in parallel orientation, the chromium-exposed cells grew as shortened fibroblasts with enlarged nuclei and granular cytoplasm, randomly orientated.

Inhalation studies have also been performed with chromium carbonyl $\left(1.6\right.$ or $\left.0.16 \mathrm{mg} / \mathrm{m}^{3}\right)$ in rabbits and rats during 4 months, and loss of body weight as well as anemia and leukocytosis were observed (Roschina, 1976). In this paper we don't note any difference in body weight and in the hematological data. Only a slight lymphocytopenia was seen.

The data of this work suggest that $\mathrm{Cr}^{3+}$ has a direct participation in liver structures alterations.

SILVA, R. F.; LOPES, R. A.; SALA, M. A.; VINHA, D.; REgALO, S. C. H.; SOUZA, A. M. \& GREGÓRIO, Z. M. O. Acción del cromo trivalente sobre las estructuras hepáticas de ratas. Estudios histométrico y hematológico. Int. J. Morphol., 24(2):197-203, 2006.

RESUMEN: El cromo trivalente $\left(\mathrm{Cr}^{3+}\right)$ es un nutriente esencial involucrado en la regulación del metabolismo de carbohidratos, lípidos y proteínas, a través de un estímulo a la acción de la insulina. El objetivo del presente trabajo fue caracterizar histopatológicamente e histométricamente las alteraciones hepáticas de ratas Wistar hembras, provocadas por la administración de cromo III en agua potable. Ratas adultas recibieron ración y agua potable ad libitum, conteniendo 300 ó 500 mg/l de cromo III, durante 4 meses. Los animales control recibieron solo agua y ración. Todos los animales fueron sacrificados con dosis letal de anestésico. Muestras de hígado, fijadas en formol al $10 \%$ por $24 \mathrm{~h}$, fueron cortadas a $6 \mu \mathrm{m}$ y teñidas con hematoxilina y eosina o PAS. Además del examen histopatológico, fueron usadas técnicas histométricas. La sangue fue recolectada y procesada para estudio hematológico. El análisis histopatológico reveló, en la zonas periportal, intermediaria y pericentrolobular, células parenquimatosas con grados variables de vacuolización. Muchos hepatocitos mostraban degeneración baloniforme con núcleos lisados. La vena centrolobular estaba dilatada y congestionada. Se observaron sinusoides dilatados conteniendo eritrocitos. La zona porta mostró fibrosis y proliferación de ductos biliares con pequeñas células. La histometría mostró aumento de los volúmenes de citoplasma y celular, y valores menores para el número de hepatocitos por $\mathrm{mm}^{3}$. Linfopenia fue observada en los animales tratados con $500 \mathrm{mg} / \mathrm{l} \mathrm{de} \mathrm{Cr}^{3+}$. Estos resultados indican que el cromo III tiene una participación directa en las alteraciones de las estructuras hepáticas.

PALABRAS CLAVE: Hígado; Rata; Cromo; Morfometría; Hematología.

\section{REFERENCES}

Anderson, R.A. Chromium metabolism and its role in disease process in man. Clin. Physiol. Biochem., 4:3141, 1986.

Anderson, R. A. Essentiality of chromium in humans. Sci. Total Environm., 86:75-81, 1989.

Anderson, R. A. Recent advances in the clinical and biochemical effects of chromium deficiency. In: Essential and toxic trace elements in human health and disease: an update. New York, Wiley-Liss, Inc., 1993. pp. 221-34.

Davies, J. M. G. The fibrinogenic effects of mineral dusts injected into the pleural cavity of mice. Brit. J. Exp. Pathol., 53:190-201, 1972. 
Dey, S. K.; Nayak, P. \& Roy, S. Alpha-tocopherol supplementation on chromium toxicity: a study on rat liver and kidney cell membrane. J. Environm. Sci., 15: 356-9, 2003.

Dey, S. K.; Nayak, P. \& Roy, S. Chromium-induced membrane damage: protective role of ascorbic acid. $J$. Environm. Sci., 13:272-5, 2001.

Evans, G. W. The effect of chromium picolinate on insulin controlled parameters in humans. Int. J. Biosoc. Med. Res., 11:163-80, 1989.

Febel, H.; Szegedi, B. \& Huszar, S. Absorption of inorganic, trivalent and hexavalent chromium following oral and intrajejunal doses in rats. Acta Vet. Hung., 49:203-9, 2001.

Langard, S. \& Hensten-Pettersen, A. Chromium toxicology. In: Williams, D. F. (ed.). Systemic aspects of biocompatibility. Boca Raton, Florida, CRC Press, 1981. V. 1. pp. 144-61.

Lukaski, H. C. Chromium as a supplement. Ann. Rev. Nutr., 19:279-302, 1999.

Mertz, M. Effects and metabolism of glucose tolerance factor. Nutr. Rev., 33:129-35, 1975.

Merz, W.A. Die Streckenmessung an gerichteten Strukturen im Mikroskop und ihre anwendung zur Bestimmung von Oberflächen-Volumen-relationen in Knochengewebe. Mikroskopie, 22:132-42, 1968.

Mosinger, M. \& Fiorentini, H. Sur la pathologie due aux chromates: Premières recherches experimentales. Arch. Mal. Prof. Méd. Trav. Sécur. Soc., 15:187-99, 1954.

Nielsen, F. H. Chromium. In: Shils, M.E.; Olson, J.A. \& Shike, M. (eds.). Modern nutrition in health and disease. 8th ed. Philadelphia, Lea Febiger, 1993, pp. 264-8.

Okada, S.; Tsukada, H. \& Ohba, H. Enhancement of ribonucleic acid synthesis by chromium (III) in regeneratin rat liver. J. Inorg. Biochem., 19:95-103, 1983.

Okada, S.; Tsukada, H. \& Ohba, H. Enhancement of nucleolar RNA synthesis by chromium (III) in regeneratin rat liver. J. Inorg. Biochem., 21:113-24, 1984.

Polak, L.; Turk, J. L. \& Frey, J.R. Studies on contact hypersensitivity to chromium compounds. In: Kallos, P.; Waksman, B. H. \& DeWeck, A. (eds.). Progress in allergy. Basel, Karger, 1973. V. 17, pp. 145-226.
Roschina, T. A. The toxicity of chrominum (sic) hexacarbonyl. Gig. Tr. Prof. Zabol., 2:38-42, 1976.

Sala, M. A.; Komesu, M. C.; Lopes, R. A. \& Maia Campos, G. Karyometric study of basal cell carcinoma. Braz. Dental J., 5:11-4, 1994.

Sala, M. A.; Lopes, R. A. \& Matheus, M. Método morfológico para análisis cuantitativa de los tejidos. Determinación de los parámetros normales para el hepatocito de rata. Arch. Fac. Med. Zaragoza, 32:2931, 1992.

Swensson, A. Experimental research on the fibrogenetic effect of chromite. Arb. Hälsa, 2:1-14, 1977.

Tandon, S. K.; Saxena, D. K.; Gaur, J. S. \& Chandra, S.W. Comparative toxicity of trivalent and hexavalent chromium: Alterations in blood and liver. Environm. Res., 15:90-9, 1978

Tazelaar, D. J. Hypersensitivity to chromium in a light-blue tattoo. Dermatologica, 141:282-7, 1970.

Vincent, J. B. Mechanisms of chromium action: Lowmolecular-weight chromium-binding substance. J. Am. Coll. Nutr., 18:6-12, 1999.

Wacker, W. E. C. \& Vallee, B.L. Nucleic acids and metals. I. Chromium, manganese, nickel, iron, and other metals in ribonucleic acid from diverse biological sources. J. Biol. Chem., 234:3257-62, 1959.

Correspondence to:

Prof.Dr. Ruberval A. Lopes

Faculdade de Odontologia de Ribeirão Preto - USP

Av. do Cafe, $s / n$.

CEP 14040-904

Ribeirão Preto - S.P.

BRASIL

$\mathcal{T e l}+55-16-36023976, \mathcal{F a x}:+55-16-36330999$.

e-mail: ruberlopes@yahoo.com.6r

Received : 22-01-2006

Accepted: 10-03-2006 